EAuthor(s)

Alves LFA'
Mamprim AP'
Formentini MA"
Martins CC'
Pinto FG'
I State University of Western Paraná,
Laboratory of Agricultural Biotechnology,
Rua Universitária, 2069, 85814110,
Cascavel, Paraná, Brazil
" Koppert Biological Systems, Piracicaba, SP

\section{nail Address}

Corresponding author e-mail address Luis Francisco Angeli Alves

State University of Western Paraná, Laboratory of Agricultural Biotechnology, Rua Universitária, 2069 85814110. Cascavel, Paraná, Brazil E-mail: luis.alves@unioeste.br

\section{nKeywords}

Entomopathogenic fungus. Compatibility. Associated control. Animal production.

\section{ABSTRACT}

This study aimed at evaluating the effect of the use of disinfectants and insecticides recommended for the control of pathogens and insects in poultry houses on the biological parameters of the entomopathogenic fungus Beauveria bassiana strain Unioeste 4. Disinfectants and insecticides were used at recommended concentration (RC), half the recommended concentration (0.5RC), and twice there commended concentration (2RC). All treatments were sprayed on the fungus previously inoculated on PDA culture media. Germination, colony forming unit (CFU), vegetative growth and conidial yield were evaluated. Germination was the most affected parameter by insecticides, with reduction of up to $25 \%$ using Couro Limpo and Cypermil products. Cypermil also reduced the vegetative growth in all tested concentrations. Conidial production was reduced when products were used at the highest concentration. On the other hand, the confirmed mortality of the lesser mealworm by the fungus was not affected by none of the tested products. All disinfectants at the highest concentration reduced germination and conidia production, but did not affect fungus vegetative growth. The confirmed mortality by the fungus was most influenced by the product TH4. All tested products tested were considered compatible with the fungus.

\section{INTRODUCTION}

The intensive production of broilers is characterized by the confinement of large numbers of individuals in a small area, which provides high productivity. However, these houses, together with the presence of organic waste (from feed and feces), provide favorable shelter, temperature, light, and moisture conditions for the development of large populations of the lesser mealworm (Alphitobius diaperinus Panzer) (Coleoptera: Tenebrionidae) and sources of the inoculum of Salmonella. These can reduce flock productivity and damage the health of animals and of the humans involved in the production chain, including consumers. It is emphasized that these species have a prominent place in poultry industry worldwide, and cause significant losses, and therefore, need to be eradicated (Axtell, 1999; Silva \& Duarte, 2002; Brasil, 2003; Penha, 2008; Hazeleger et al., 2008; Omalu et al., 2012).

Despite the current poultry management practices recommended for the control and elimination of pathogens, little progress has been made in the search of alternatives to the use of chemical disinfectants, which are commonly applied, such as quaternary ammonium compounds, glutaraldehyde, sodium hypochlorite, and organic acids (Jaenisch et al., 2010).

Chemical control is the main strategy applied for the control of the lesser mealworm. The most common products are pyrethroid insecticides, which are continuously applied, with or without poultry litter (Santos et al., 2009). However, many natural enemies of the lesser 
Effect of Disinfectants and Pesticides Used in Poultry Houses on Beauveria Bassiana (Bals.) Vuill.fungus mealworm are found in poultry houses, including predators and entomopathogenic fungi (Alves et al., 2004; 2005; Santoro et al., 2010). The potential of such fungi for lesser mealworm control was demonstrated both under laboratory and field conditions (Geden et al., 1998; Rohde et al., 2006, Chernaki et al., 2007). In addition, it is safe for poultry (Hass et al., 2010).

However, poultry house management practices may interfere with the activity and survival of the fungus. Previous studies showed that litter chemical composition, structure, and temperature may negatively affect fungus survival, and therefore, its activity against both lesser mealworm larvae and adults (Bacon, 1985; Alexandre et al., 2006; Alves et al., 2008). In our previous studies with Beauveria bassiana isolate Unioeste 4 applied to the soil or combined with poultry litter, the population of lesser mealworm was reduced in $80 \%$ (Alves et al., 2015).

When used for the control of pests, fungi are also part of the poultry management system, as well as chemical disinfectants and insecticides (Bellaver et al., 2003). However, such chemicals must be rationally applied, i.e., the preservation of natural pest enemies and the health of poultry and humans must be taken into account. Although many studies on the impact organic-synthetic pesticides on natural pest enemies were published, no such articles were found in the context of poultry production, nor specifically on the fungus $B$. bassiana. Therefore, the objective of, this experiment was to evaluated the effects of disinfectants and insecticides commonly used in poultry houses on the fungus $B$. bassiana strain Unioeste 4 in order make recommendations for their application.

\section{MATERIAL AND METHODS}

\section{Chemical products}

Commercial disinfectants and insecticides registered for poultry house application were used at the concentration recommended by the manufacturer $(R C)$, half the recommended concentration $(0.5 R C)$, or twice the recommended concentration (2RC) (Table 1).

\section{Microorganism}

Beauveria bassiana isolate Unioeste 4 was obtained from culture collection of Laboratório de Biotecnologia Agrícola da Unioeste (http://splink.cria. org.br/manager/detail?resource=CFEUnioeste). Fungal conidia were obtained from 10-day-old colonies grown in Petri dishes with culture medium (20 g agar, $5 \mathrm{~g}$ yeast extract, $4.6 \mathrm{~g}$ salt mixture, $10 \mathrm{~g}$ glucose, and $1000 \mathrm{~mL}$ distilled water).
Table 1 - Products used in the experiments and their respective composition, as described from manufacturer

\begin{tabular}{|c|c|}
\hline Brand name & Composition $^{1}$ \\
\hline \multicolumn{2}{|l|}{ Insecticides } \\
\hline Couro Limpo & $\begin{array}{l}\text { Cypermethrin } 15 \mathrm{~g} \text {, Chlorpyrifos } 25 \mathrm{~g} \text {; Citronellal } 1 \mathrm{~g} \text {, } \\
\text { q.s.p. vehicle } 100 \mathrm{~mL}-25 \mathrm{~mL} / 20 \mathrm{~L}\end{array}$ \\
\hline Colosso & $\begin{array}{l}\text { Cypermethrin } 15 \mathrm{~g} \text {, Chlorpyrifos } 25 \mathrm{~g} \text {; Citronellal } 1 \mathrm{~g} \text {, } \\
\text { q.s.p. vehicle } 100 \mathrm{~mL}-25 \mathrm{~mL} / 20 \mathrm{~L}\end{array}$ \\
\hline Cypermil & Cypermethrin 15 g; vehicle q.s.p. $100 \mathrm{~mL}-20 \mathrm{~mL} / 20 \mathrm{~L}$ \\
\hline \multicolumn{2}{|l|}{ Disinfectants } \\
\hline Aviclor & $\begin{array}{l}\text { 1,3,5 triazine, } 2,4,6 \text { trione, } 1,3 \text { dichlor sodium } 75 \% \text {; } \\
\text { adjuvant } 0.248 \% \text {; excipient } 22.52 \%-1 \mathrm{~kg} / 1000 \mathrm{~L}- \\
1 \mathrm{~kg} / 1000 \mathrm{~L}\end{array}$ \\
\hline AVT 80 & $\begin{array}{l}\text { Benzalkonium chloride } 64 \% \text {; q.s.p. vehicle } 36 \% \text { - } \\
250 \mathrm{~mL} / 1000 \mathrm{~L}\end{array}$ \\
\hline CB-30 TA & $\begin{array}{l}\text { Benzalkonium chloride } 30 \mathrm{~g} \text {, nonyl phenoxy polyethoxy } \\
\text { ethanol } 5 \mathrm{~g} \text {; vehicle q.s.p. }-10 \mathrm{~mL} / 20 \mathrm{~L}\end{array}$ \\
\hline Glutasil & $\begin{array}{l}\text { Glutaraldehyde } 42,5 \% \text {, benzalkonium chloride } 7,5 \% \text {, } \\
\text { vehicle q.s.p. } 100 \mathrm{~mL}-\mathrm{L} 1 \mathrm{~L} / 100\end{array}$ \\
\hline Glutaquat & $\begin{array}{l}\text { Glutaraldehyde } 40 \mathrm{~g} \text {, benzalkonium chloride } 10 \mathrm{~g} \text {, } \\
\text { vehicle q.s.p. } 100 \mathrm{~mL}-\mathrm{L} 1 \mathrm{~L} / 1000\end{array}$ \\
\hline Kilol ${ }^{\circledast}$ & $\begin{array}{l}1 \mathrm{~mL} \text { ascorbic acid, } 0.475 \mathrm{~mL} \text { citric acid, } 0.47 \mathrm{~mL} \text { lactic } \\
\text { acid, water q.s.p. } 100 \mathrm{~mL}-1 \mathrm{~L} / 250 \mathrm{~L}\end{array}$ \\
\hline TH4 & $\begin{array}{l}\text { Didecyldimethylammonium chloride } 1.87 \mathrm{~g} \text {; } \\
\text { dioctyldimethylammoniumchloride } 1.87 \mathrm{~g} ; \\
\text { octyldecyldimethylammonium chloride } 3.7 \mathrm{~g} \text {; } \\
\text { alkyldimethylbenzylammonium chloride } 5 \mathrm{~g} \text {; } \\
\text { glutaraldehyde } 6.2 \mathrm{~g} \text {; pine oil } 2 \mathrm{~g} \text {, terpineol } 2 \mathrm{~g} \text {; vehicle } \\
\text { q.s.p. } 100 \mathrm{~mL}-1 \mathrm{~L} / 200 \mathrm{~L}\end{array}$ \\
\hline
\end{tabular}

${ }^{1}$ Information provided by the manufacturers

\section{B. bassiana biological parameters}

The following biological parameters were used to evaluate the effects of the applied chemical products on $B$. bassiana: conidial germination, colony forming units (CFU), vegetative growth, and conidial production (Alves et al., 1998a; Silva et al., 2005; Oliveira, 2009).

A) Germination: $300 \mu \mathrm{L}$ of a conidial suspension $\left(1 \times 10^{6}\right.$ conidia/mL) was inoculated onto PDA culture media in Petri dishes, which were lightly shaken to spread the suspension. Then, $250 \mu \mathrm{L}$ of the solutions of the chemical products were sprayed onto the surface of the culture media with an airbrush coupled to a continuous airflow compressor $\left(0.84 \mathrm{kgf} / \mathrm{cm}^{2}\right)$. Dishes were incubated at $26^{\circ} \mathrm{C}$ for $16 \mathrm{~h}$ under a12-h photoperiod, after which germinated and nongerminated conidia were counted under an optical microscope totaling, on average, approximately 200 conidia/plate; the presence of germ tubes (showing at least twice the conidial diameter) was considered.

B) Colony Forming Units (CFU): $100 \mu \mathrm{L}$ of a conidial suspension $\left(1 \times 10^{3}\right.$ conidia $\left./ \mathrm{mL}\right)$ were inoculated according to the same procedures as described above, and incubated for five days, after which the colonies formed were counted.

C) Vegetative growth: the fungus was inoculated using a platinum loop at 3 points on the surface of 
potato dextrose agar (PDA) culture medium, incubated at $26{ }^{\circ} \mathrm{C}$ under a 12-h photoperiod for $48 \mathrm{~h}$, after which the chemical products were sprayed. Plates were again incubated under the same conditions for 7 days. Two perpendicular measures of the colonies were performed to evaluate vegetative growth.

D) Conidia production: after evaluating vegetative growth, a colony in each plate was cut and transferred to a sterile glass flasks containing sterilized distilled water $+0.01 \%$ Tween $\circledR 80$. Flasks were agitated for 1 min and conidia were counted in a Neubauer chamber.

A completely randomized experimental design with insecticides and disinfectants with four replicates each was applied. Data were submitted to analysis of variance ( $F$ test) and means were compared by the Scott Knott test at 5\% significance level, using Sisvar software (Ferreira, 2011).

The effect of the evaluated products on the fungus was evaluated according to the equation proposed by Rossi-Zalaf et al., (2008), as: Bl: 47[CV] + 43[ESP] + 10[GER]/100, where: IB = Biological Index, CV = vegetative growth percentage of the colony after 7 days relative to the control, ESP $=$ percentage of sporulation of colonies after 7 days compared with the control; GER = percentage of conidia germination after $16 \mathrm{~h}$. The $\mathrm{BI}$ values $(p=0.05)$ used for products classification were: Toxic 0-41, Moderately Toxic 4266, and Compatible>66.

E) Insecticidal activity of $B$. bassiana: Conidia were applied to the surface of the PDA culture medium, spread with a Drigalski handle, and then sprayed with $250 \mu \mathrm{L}$ of each product/plate. Plates were incubated for 7 days at $26 \pm 1{ }^{\circ} \mathrm{C}$ and 12 -h photoperiod. Conidia were collected and the suspensions were prepared (1 $\times 10^{8}$ conidia $/ \mathrm{mL}$ ) in a glass tube according to Rohde et al., (2006). Adults of the lesser meal worm were immersed in the suspensions and, after manual stirring for 1 minute, were transferred to Petri dishes to remove fluid excess and transferred to other Petri dishes containing poultry feed.

One plate was not sprayed and used as control. Insects were immersed as described above in distilled water +0.01 Tween ${ }^{\circledR} 80$. The insects were kept at 26 $\pm 1{ }^{\circ} \mathrm{C}$ and a $12 \mathrm{~h}$ photophase. Daily mortality was assessed for 10 days. Dead insects were immersed in $70 \%$ ethanol and then in distilled water and kept in a moist chamber (confirmed mortality by the fungus), observing signs and symptoms of fungal infection as described by Alves et al., (1998b).

For each product, five plates with 15 adults were prepared, and each plate was considered a replicate. Data were analyzed for normality by the Shapiro-Wilk test and transformed when necessary. Subsequently, data were submitted to analysis of variance ( $F$ test) and means were compared by the Scott-Knott test (5\% significance level) using Sisvar software.

\section{RESULTS AND DISCUSSION}

\section{Insecticides}

All products tested significantly reduced conidial germination, notably Couro Limpo and Colosso products, both at the recommended concentration (RC), but there was no effect on CFU. Colony diameter was significantly reduced by Couro Limpo and Colosso products, both at 2RC, and by Cypermil at all concentrations tested. Conidial production was significantly lower only when products were used at2 RC. However, all products evaluated were considered compatible with fungus, with $\mathrm{BI}$ values higher than the minimum considered (Table 2).

Table 2 - Mean values of biological parameters and biological index of the fungus Beauveria bassiana (strain Unioeste 4) obtained in culture medium containing insecticides $\left(26 \pm 2^{\circ} \mathrm{C}, \mathrm{RH}: 60 \pm 10 \%\right.$; photophase: $\left.14 \mathrm{~h}\right)$.

\begin{tabular}{|c|c|c|c|c|c|c|c|}
\hline Products & Germination (\%) & CFU & Diameter $(\mathrm{cm})$ & conidia $\left(\times 10^{6} / \mathrm{mL}\right)$ & $\left.B\right|^{2}$ & Total mortality (\%) & Confirmed mortality (\%) \\
\hline Fungus & $100.00 \mathrm{a}$ & $202.75 \mathrm{a}$ & $2.67 \mathrm{a}$ & $58.95 a$ & - & $100.0 \pm 0.0 \mathrm{a}$ & $88.0 \pm 3.8 \mathrm{a}$ \\
\hline Couro limpo (0.5RC) & $88.32 b$ & $213.75 \mathrm{a}$ & $2.68 \mathrm{a}$ & $45.85 a$ & $80.37 \mathrm{C}$ & $90.6 \pm 3.4 b$ & $84.0 \pm 4.99 a$ \\
\hline Couro limpo (RC) & $75.01 \mathrm{c}$ & $202.50 \mathrm{a}$ & $2.71 \mathrm{a}$ & 48.63 a & $82.28 \mathrm{C}$ & $98.6 \pm 1.3 \mathrm{a}$ & $90.6 \pm 4.9 a$ \\
\hline Couro limpo (2RC) & $83.10 b$ & $213.25 a$ & $2.59 b$ & $44.09 b$ & $76.61 \mathrm{C}$ & $100.0 \pm 0.0 a$ & $96.0 \pm 2.6 \mathrm{a}$ \\
\hline Colosso (0.5RC) & $85.60 \mathrm{~b}$ & $202.00 \mathrm{a}$ & $2.68 \mathrm{a}$ & 54.07 a & $91.90 \mathrm{C}$ & $98.6 \pm 1.3 a$ & $93.3 \pm 5.1 \mathrm{a}$ \\
\hline Colosso (RC) & $75.91 \mathrm{C}$ & $229.50 \mathrm{a}$ & $2.69 \mathrm{a}$ & $52.93 \mathrm{a}$ & $81.49 C$ & $94.6 \pm 2.4 b$ & $81.3 \pm 4.4 a$ \\
\hline Colosso (2RC) & $80.76 b$ & $218.50 \mathrm{a}$ & $2.61 \mathrm{~b}$ & 39.04 b & $79.31 \mathrm{C}$ & $94.6 \pm 1.3 b$ & $87.9 \pm 3.27 \mathrm{a}$ \\
\hline Cypermil (0.5RC) & $84.56 \mathrm{~b}$ & $226.00 \mathrm{a}$ & $2.62 \mathrm{~b}$ & $54.60 \mathrm{a}$ & $89.97 C$ & $91.9 \pm 3.2 b$ & $85.3 \pm 6.4 a$ \\
\hline Cypermil (RC) & $85.24 b$ & $192.50 \mathrm{a}$ & $2.52 \mathrm{C}$ & $51.99 \mathrm{a}$ & $83.90 \mathrm{C}$ & $100.0 \pm 0.0 a$ & $93.3 \pm 5.16 a$ \\
\hline Cypermil (2RC) & $82.56 \mathrm{~b}$ & $204.00 \mathrm{a}$ & $2.53 c$ & $34.04 b$ & $71.09 \mathrm{C}$ & $98.6 \pm 1.33 \mathrm{a}$ & $93.3 \pm 2.9 a$ \\
\hline C.V. & 5.59 & 15.32 & 1.75 & 15.26 & - & 4.91 & 11.92 \\
\hline
\end{tabular}

Information collected from manufacturers

Means ( \pm MSE) followed by the same letter in the column do not differ by the Scott Knott test $(p<0.05)$

'Products concentrations: $0.5 \mathrm{RC}=$ Half the recommended concentration, $\mathrm{RC}=$ Recommended Concentration; $2 \mathrm{RC}=$ Twice the recommended concentration.

${ }^{2} \mathrm{IB}=$ biological index, according to Rossi-Zalaf et al., (2008): 0 to $41=$ toxic (T); $42-66=$ moderately toxic (MT); greater than $66=$ compatible (C) 
Germination it was the biological parameter that was most affected by insecticides. Conidial germination is essential to initiate the infectious process in the host, and it is more important than vegetative growth or conidial production of B. bassiana (Feng et al.,1994; Todorova et al., 1998).

The objective of the applied methodology was to simulate actual conditions of fungus exposure to the chemical products, as indicated by Oliveira \& Neves (2004), and therefore, the responses obtained in the present experiment actually express the interaction between the fungus and the products and their impact on the evaluated parameters.

The negative effect of cypermethrin on colony diameter was also verified by Lecuona et al., (2001), when evaluating associations of $B$. bassianawithchemical insecticides for the control of Triatoma infestans. Those authors reported that such associations are only possible when insecticides were applied at $10 \%$ of the recommended concentration.

It is difficult to explain the different results obtained with insecticides, since cypermethrin is the active ingredient of three tested products. On the other hand, the similar effects of Couro Limpo and Colosso on all parameters may be explained by their identical composition.

Maintaining the integrity of the outer surface of the conidia is important for the germination process. The components of the chemical products may affect such integrity, and therefore, fungal germination (Boucias et al., 1988;St. Leger et al., 1991). Germination may also be reduced when certain molecules bind to receptors in the fungal cytoplasm, affecting membrane permeability and enzyme synthesis, changing conidial metabolism (Moore-Landecker1982; Ghini \& Kimati 2000; Oliveira \& Neves, 2004).

The evaluated insecticides had no effect on colony formation (CFU), indicating that the metabolism was not affected at this level. Although it is likely that the products applied on the medium surface, being in contact with the cells of the fungus, have been widely spread, were absorbed by the fungus and accumulated in the cytoplasm over five days of incubation; however, concentration required to inhibit fungal metabolism was probably not reached (Kimati, 1995).

The incubation time used to evaluate vegetative growth was higher than CFU incubation time, demonstrating a direct relation of the insecticides on vegetative growth as contact time increased. It is possible that the chemical compounds accumulated in the fungal cytoplasm, and affected its enzymatic apparatus. It is noteworthy that the $2 \mathrm{RC}$ concentrations is not applied in field conditions, and in-vitro assay shows an extreme contact. Also, mycelial growth stage develops inside the body of the insect host, where the insecticidal concentrations are usually low, negative effects of insecticides on this developmental stage are unlikely (Khalil et al., 1985).

The insecticidal activity of the fungus produced when insecticides were applied on the culture media was reduced (total mortality was 10\% lower than control) with Couro Limpo and Cypermil, both at 0.5 RC, and with Colosso at 1 and 2 RC. However, there were no differences in confirmed mortality when comparing the fungi grown in culture media either with or without the evaluated products (Table 2).

Therefore, it is possible the effects of either the active ingredients or adjuvants in the insecticide formulations on fungal germination or growth did not cause any changes in the synthesis toxins or enzymes, which are important for host colonization by the fungus (Xiao et al., 2012), as shown by the lack of differences in confirmed mortality. On the other hand, the absence of effect on confirmed mortality may also indicate that the fungus developed on a substrate (insect cadaver) where the evaluated products were not present, therefore precluding any negative on the fungus.

Although the total mortality of insects inoculated with fungi grown in insecticide-containing media was reduced, this result should not be understood as reduced fungal efficiency caused by the insecticides, as the objective was merely to assess the in-vitro biological effects of the insecticides on fungal activity. Under field conditions, the concentrations of insecticide in the insect body are much lower than those used in the culture media, and therefore, the application of the insecticides tested in the present experiment may not impact the fungus present in poultry houses (in case of natural occurrence or to control the lesser mealworm). On the other hand, the fungi may also remain in the environment, despite the effects observed here, as they multiply in insect cadavers that may not have been affected by the chemical products.

Agricultural pyrethroid insecticides are evaluated as a function of their positive and negative inhibitory actions on entomopathogenic fungi, and may vary according to product concentration, active ingredient, formulation, and type of adjuvant, as well as to the evaluation technique and fungal strains and species involved (Lecuona \& Diaz, 2001; Lecuona et al., 2001; Barci et al., 2009). However, as there are no reports of such studies with poultry, conclusions of such studies are only valid under the conditions of each experiment and should not be generalized. 


\section{Disinfectants}

All evaluated disinfectants reduced fungal germination, specially at $R C$ and $2 R C$, in relation to the controls. In particular, the products AVT80 and Glutasil at $\mathrm{RC}$ and $2 \mathrm{RC}$ reduced conidial germination between 20 and $25 \%$.

There were no significant effects on vegetative growth parameters (CFU formation and colony diameter), as previously observed with the insecticides (Table 3).

On the other hand, conidial production/colony was greatly affected by AVT80 at 2RC, CB-30 at 2RC, Glutaquat at RC and 2RC (50\%), and Kilol at RC and 2 RC (40\%).

Despite these values, all disinfectants, as observed with insecticides, were compatible with the fungus, with $B I$ values above the minimum required for them to be considered compatible.

Overall, the effects of disinfectants on fungal viability and vegetative growth were less severe than those observed with insecticides, although both have antimicrobial activity.
The product Glutaquat (at all concentrations) and Glutasil (at 2RC) showed an inhibitory effect on conidial production/colony. Glutaraldehyde acts on fungi, especially on the cell walls, interacting with chitin, promoting injury (McDonnell \& Russell, 1999; Ristow, 2008). Benzalkonium chloride present in the AVT80 and CB30 products (main compound) and Glutaquat and Glutasil at 2RC (minor compound) is a cationic surfactant that modifies the lipid structure of the surface plasma membrane of the conidia, thereby affecting germination (McDonnell \& Russell, 1999; Ristow, 2008).

The observed absence or weak effects of the tested disinfectants on B. bassiana germination, CFU, and diameter may be ascribed to the metabolism of this fungus, which has a rich enzymatic apparatus and may have broken down the molecules of the tested products (Moino Jr. \& Alves, 1998; Silva \& Espósito, 2004). In addition, the diffusion capacity of the compounds tested in the culture media may have been low, therefore the contact with the fungus may have been reduced. As Anderson \& Roberts (1983) demonstrated that the

Table 3 - Biological parameters and biological index of the fungus Beauveria bassiana (strain Unioeste 4) obtained in culture medium containing disinfectant products $\left(26 \pm 2{ }^{\circ} \mathrm{C}, \mathrm{RH}: 60 \pm 10 \%\right.$; photophase: $\left.14 \mathrm{~h}\right)$.

\begin{tabular}{|c|c|c|c|c|c|c|c|}
\hline Products & Germination (\%) & CFU & Diameter(cm) & conidia $\left(\times 10^{6} / \mathrm{mL}\right)$ & $B 1^{2}$ & Total mortality (\%) & Confirmed mortality (\%) \\
\hline \multicolumn{8}{|l|}{ Disinfectants } \\
\hline Control & $98.3 \mathrm{a}$ & $44.75 \mathrm{a}$ & $2.65 \mathrm{a}$ & $69.0 \mathrm{a}$ & - & $88.0 \pm 3.8 b$ & $88.0 \pm 3.8 a$ \\
\hline Aviclor (0.5RC) & $91.8 \mathrm{a}$ & $34.50 \mathrm{a}$ & $2.61 \mathrm{a}$ & $61.9 \mathrm{a}$ & $87.1 \mathrm{C}$ & $100.0 \pm 0.0 a$ & $100.0 \pm 0.0 \mathrm{a}$ \\
\hline Aviclor (RC) & $75.5 b$ & $43.25 \mathrm{a}$ & $2.63 \mathrm{a}$ & $52.6 \mathrm{~b}$ & $79.0 \mathrm{C}$ & $95.9 \pm 1.6 \mathrm{a}$ & $81.3 \pm 7.4 b$ \\
\hline Aviclor (2RC) & $86.5 \mathrm{a}$ & $40.25 \mathrm{a}$ & $2.56 \mathrm{a}$ & $46.9 c$ & $77.0 \mathrm{C}$ & $86.6 \pm 3.6 b$ & $86.6 \pm 3.6 a$ \\
\hline AVT 80(0.5RC) & $91.8 \mathrm{a}$ & 35.25 a & $2.63 \mathrm{a}$ & $43.8 c$ & $81.2 \mathrm{C}$ & $90.6 \pm 1.6 b$ & $90.6 \pm 1.6 a$ \\
\hline AVT 80(RC) & $75.5 b$ & $43.25 \mathrm{a}$ & $2.63 \mathrm{a}$ & $39.9 \mathrm{C}$ & $72.2 \mathrm{C}$ & $93.3 \pm 4.2 b$ & $92.0 \pm 5.3 a$ \\
\hline AVT 80 (2RC) & $80.7 b$ & $41.00 \mathrm{a}$ & $2.63 \mathrm{a}$ & $36.4 d$ & $71.2 \mathrm{C}$ & $100.0 \pm 0.0 \mathrm{a}$ & $100.0 \pm 0.0 \mathrm{a}$ \\
\hline CB-30 TA $(0.5 R C)$ & $93.1 \mathrm{a}$ & $41.50 \mathrm{a}$ & $2.59 a$ & $55.7 b$ & $82.5 \mathrm{C}$ & $98.6 \pm 1.3 a$ & $96.0 \pm 2.6 a$ \\
\hline CB-30 TA $(R C)$ & $86.6 \mathrm{a}$ & $47.00 \mathrm{a}$ & $2.58 \mathrm{a}$ & $43.2 c$ & $67.0 \mathrm{C}$ & $100.0 \pm 0.0 \mathrm{a}$ & $100.0 \pm 0.0 \mathrm{a}$ \\
\hline CB-30 TA (2RC) & $79.6 b$ & $42.00 \mathrm{a}$ & $2.58 \mathrm{a}$ & $33.0 \mathrm{~d}$ & $68.0 \mathrm{C}$ & $98.6 \pm 1.3 a$ & $98.6 \pm 1.3 a$ \\
\hline Glutaquat (0.5RC) & 89.9 a & $42.00 \mathrm{a}$ & $2.66 \mathrm{a}$ & $44.6 \mathrm{c}$ & $78.5 \mathrm{C}$ & $95.9 \pm 1.6 \mathrm{a}$ & $68.0 \pm 8.2 b$ \\
\hline Glutaquat (RC) & $92.8 \mathrm{a}$ & $43.25 \mathrm{a}$ & $2.59 \mathrm{a}$ & $36.8 d$ & $63.4 \mathrm{C}$ & $100.0 \pm 0.0 \mathrm{a}$ & $100.0 \pm 0.0 \mathrm{a}$ \\
\hline Glutaquat (2RC) & $76.3 b$ & $40.00 \mathrm{a}$ & $2.56 \mathrm{a}$ & $37.1 \mathrm{~d}$ & $65.5 \mathrm{C}$ & $93.3 \pm 3.6 b$ & $79.9 \pm 10.3 b$ \\
\hline Glutasil 50 (0.5RC) & $88.8 \mathrm{a}$ & 45.75 a & $2.57 \mathrm{a}$ & $58.5 \mathrm{a}$ & $87.3 \mathrm{C}$ & $98.6 \pm 1.3 a$ & $98.6 \pm 1.3 a$ \\
\hline Glutasil 50 (RC) & $72.9 \mathrm{~b}$ & $39.00 \mathrm{a}$ & $2.67 \mathrm{a}$ & $58.4 \mathrm{a}$ & $86.7 \mathrm{C}$ & $100.0 \pm 0.0 \mathrm{a}$ & $86.6 \pm 11.4 \mathrm{a}$ \\
\hline Glutasil 50 (2RC) & $79.9 b$ & $41.50 \mathrm{a}$ & $2.54 \mathrm{a}$ & $42.8 c$ & $68.9 \mathrm{C}$ & $89.3 \pm 4.9 b$ & $89.3 \pm 4.9 a$ \\
\hline Kilol $^{\circledR}((0.5 R C)$ & $99.1 \mathrm{a}$ & $47.25 \mathrm{a}$ & $2.62 \mathrm{a}$ & $39.9 \mathrm{C}$ & $73.4 \mathrm{C}$ & $100.0 \pm 0.0 \mathrm{a}$ & $93.3 \pm 5.1 \mathrm{a}$ \\
\hline Kilol $^{\circledR}(\mathrm{RC})$ & $93.5 \mathrm{a}$ & $37.25 \mathrm{a}$ & $2.61 \mathrm{a}$ & $30.1 \mathrm{~d}$ & $66.4 \mathrm{C}$ & $100.0 \pm 0.0 \mathrm{a}$ & $77.3 \pm 10.8 b$ \\
\hline Kilol $^{\circledR}(2 R C)$ & $84.3 b$ & $42.50 \mathrm{a}$ & $2.73 \mathrm{a}$ & $27.0 \mathrm{~d}$ & $66.5 \mathrm{C}$ & $96.0 \pm 4.0 \mathrm{a}$ & $96.0 \pm 4.0 \mathrm{a}$ \\
\hline TH4 (0.5RC) & $84.3 b$ & 49.00 a & $2.57 \mathrm{a}$ & $49.17 b$ & $81.8 \mathrm{C}$ & $100.0 \pm 0.0 a$ & $80.0 \pm 12.2 b$ \\
\hline TH4 (RC) & 89.0 a & $42.25 \mathrm{a}$ & $2.49 \mathrm{a}$ & $49.35 b$ & $80.4 \mathrm{C}$ & $100.0 \pm 0.0 \mathrm{a}$ & $77.3 \pm 14.0 b$ \\
\hline TH4 (2RC) & $80.8 \mathrm{~b}$ & $47.50 \mathrm{a}$ & $2.62 \mathrm{a}$ & $43.80 \mathrm{c}$ & $70.7 \mathrm{C}$ & $90.6 \pm 3.4 b$ & $90.6 \pm 3.4 a$ \\
\hline C.V. & 7.78 & 22.88 & 2.84 & 17.74 & - & & \\
\hline
\end{tabular}

Means ( \pm SEM) followed by the same letter in the same column are not different by the Scott Knott test $(p<0.05)$

'Products concentrations: $0.5 \mathrm{RC}=$ half the recommended concentration, $\mathrm{RC}=$ recommended Concentration; $2 \mathrm{RC}=$ twice the recommended concentration.

${ }^{2} \mathrm{IB}=$ biological index, according to Rossi-Zalaf et al., (2008): 0 to $41=$ toxic (T); 42-66 = moderately toxic (MT); greater than $66=$ compatible (C)

$\mathrm{RC}=$ recommended concentration; C.V.= Coefficient of Variation; CFU=Colony Forming Units 
Effect of Disinfectants and Pesticides Used in Poultry Houses on Beauveria Bassiana (Bals.) Vuill.fungus ingredients included in the disinfectant formulation may be more important than the active ingredients, allowing conidial dispersion on the surface of the medium during inoculation, promoting the development of a higher number of CFU.

In contrast, conidial production was reduced with most of the products tested, except for Aviclor 0.5 RC and Glutasil 0.5 RC and 2 RC. Kilol reduced conidial production by almost 50\%. Despite not having influenced other fungal parameters, the disinfectants may have affected some important metabolic steps in conidial production, as shown by McDonnell \& Russel (1999) in an extensive review on the mode of action of synthetic disinfectants.

Although fungal growth was not affected, it is possible that the production of toxins and enzymes important for the colonization process was negatively affected, as shown by the reduction in total and confirmed mortality (Table 4), as previously discussed in the insecticides.

Table 4 - Mortality percentage ( \pm SEM) of adults of Alphitobius diaperinus by Beauveria bassiana fungus (strain Unioeste 4) obtained in culture medium containing disinfectants $\left(26 \pm 2{ }^{\circ} \mathrm{C}, \mathrm{RH}: 60 \pm 10 \%\right.$; photophase: $\left.14 \mathrm{~h}\right)$.

\begin{tabular}{lcc}
\hline Treatment & Total mortality $(\%)$ & Confirmed mortality (\%) \\
\hline Control & $6.6 \pm 5.1 \mathrm{c}$ & $0.0 \pm 0.0 \mathrm{c}$ \\
Fungus & $88.0 \pm 3.8 \mathrm{~b}$ & $88.0 \pm 3.8 \mathrm{a}$ \\
\hline CB-30 0.5RC & $100.0 \pm 0.0 \mathrm{a}$ & $100.0 \pm 0.0 \mathrm{a}$ \\
CB-30 RC & $95.9 \pm 1.6 \mathrm{a}$ & $81.3 \pm 7.4 \mathrm{~b}$ \\
CB-30 2RC & $86.6 \pm 3.6 \mathrm{~b}$ & $86.6 \pm 3.6 \mathrm{a}$ \\
Glutasil 0.5RC & $90.6 \pm 1.6 \mathrm{~b}$ & $90.6 \pm 1.6 \mathrm{a}$ \\
Glutasil RC & $93.3 \pm 4.2 \mathrm{~b}$ & $92.0 \pm 5.3 \mathrm{a}$ \\
Glutasil 2RC & $100.0 \pm 0.0 \mathrm{a}$ & $100.0 \pm 0.0 \mathrm{a}$ \\
\hline TH4 0.5RC & $98.6 \pm 1.3 \mathrm{a}$ & $96.0 \pm 2.6 \mathrm{a}$ \\
TH4 RC & $100.0 \pm 0.0 \mathrm{a}$ & $100.0 \pm 0.0 \mathrm{a}$ \\
TH4 2RC & $98.6 \pm 1.3 \mathrm{a}$ & $98.6 \pm 1.3 \mathrm{a}$ \\
Aviclor 0.5RC & $95.9 \pm 1.6 \mathrm{a}$ & $68.0 \pm 8.2 \mathrm{~b}$ \\
Aviclor RC & $100.0 \pm 0.0 \mathrm{a}$ & $100.0 \pm 0.0 \mathrm{a}$ \\
Aviclor 2RC & $93.3 \pm 3.6 \mathrm{~b}$ & $79.9 \pm 10.3 \mathrm{~b}$ \\
Glutaquat 0.5RC & $98.6 \pm 1.3 \mathrm{a}$ & $98.6 \pm 1.3 \mathrm{a}$ \\
Glutaquat RC & $100.0 \pm 0.0 \mathrm{a}$ & $86.6 \pm 11.4 \mathrm{a}$ \\
Glutaquat 2RC & $89.3 \pm 4.9 \mathrm{~b}$ & $89.3 \pm 4.9 \mathrm{a}$ \\
Kilol 0.5RC & $100.0 \pm 0.0 \mathrm{a}$ & $93.3 \pm 5.1 \mathrm{a}$ \\
Kilol RC & $100.0 \pm 0.0 \mathrm{a}$ & $77.3 \pm 10.8 \mathrm{~b}$ \\
Kilol 2RC & $96.0 \pm 4.0 \mathrm{a}$ & $96.0 \pm 4.0 \mathrm{a}$ \\
AVT-80 0.5RC & $100.0 \pm 0.0 \mathrm{a}$ & $80.0 \pm 12.2 \mathrm{~b}$ \\
AVT-80 RC & $100.0 \pm 0.0 \mathrm{a}$ & $77.3 \pm 14.0 \mathrm{~b}$ \\
AVT-80 2RC & $90.6 \pm 3.4 \mathrm{~b}$ & $90.6 \pm 3.4 \mathrm{a}$ \\
\hline C.V. (\%) $=$ & 6.23 & 17.08 \\
\hline & & \\
\hline
\end{tabular}

Means $( \pm$ SEM) followed by the same letter in the column do not differ by the Scott Knott test $(p<0.05)$

$\mathrm{RC}=$ recommended concentration; $\mathrm{C} . \mathrm{V} .=$ Coefficient of Variation
The multiplication of either naturally-occurring or applied fungi in dead insects allows their permanence in poultry houses and should be preserved (Alves, 1998). Therefore, when using disinfectants in poultry houses, care must be taken to preserve those populations (Steinkraus et al., 1991; Alves et al., 2004; 2005).

In addition, it should be noted that the observed effects on fungal activity does not correspond to the reduced efficiency of a combined application of insecticides or disinfectants and the fungus. Alexandre et al. (2008), using the Colosso insecticide and $B$. bassiana Unioeste 4 strain, showed that mixtures of fungus and insecticides could be used only when the fungus was used at concentrations equivalent to $\mathrm{CL}_{70}$; the insecticide at the concentrations of $\mathrm{CL}_{5}$ and $\mathrm{CL}_{10}$ showed an additive effect. When the insecticide concentration was higher than that of the fungus, fungal activity was reduced.

So, it may be inferred that the fungal application in poultry house may be affected by the presence of the products here evaluated. However, the reduction in the inoculum potential (as that observed with the chemical treatment of the poultry house) may be overridden by fungus reapplications. In addition, the ability of the $B$. bassiana fungus to grow saprophytically in the environment and to produce secondary inoculum sources through sporulation on cadavers may potentially be used for the conservation of that entomopathogen in poultry houses.

\section{REFERENCES}

Adams CA. Nutricines: food components in health and nutrition. Nottingham: Nottingham University Press; 1999.

Alexandre TM, Alves LFA, Neves PMOJ, Alves SB. Efeito da temperatura e cama do aviário na virulência de Beauveria bassiana (Bals.) Vuill. e Metarhizium anisopliae (Metsch.) para o controle do cascudinho (Alphitobius diaperinus) (Panzer) (Coleoptera: Tenebrionidae). Neotropical Entomology 2006;35(1):75-82.

Alexandre TM, Neves PMOJ, Santoro PH, Alves LFA. Controle associado de Alphitobius diaperinus com o fungo entomopatogênico Beauveria bassiana e inseticidas químicos. Arquivos do Instituto Biológico 2008;75(4):481-489.

Alves LFA, Alves VS, Bressan DF, Neves PMOJ, Alves SB. Ocorrência de Metarhizium anisopliae (Metsch.) Sorok. em adultos de cascudinho (Alphitobius diaperinus) (Panzer) (Coleoptera: Tenebrionidae) em aviários comerciais em Cascavel, PR. Neotropical Entomology 2004;33(6):793-795.

Alves LFA, Gassen MH, Pinto FGS, Neves PMOJ, Alves SB. Ocorrência natural de Beauveria bassiana (Bals.) Vuilleman (Moniliales: Moniliaceae) sobre o cascudinho, Alphitobius diaperinus (Panzer) (Coleoptera: Tenebrionidae), em aviário comercial de Cascavel, PR. Neotropical Entomology 2005;34(3): 507-510.

Alves LFA, Neves PMOJ, Oliveira RC, Oliveira DGP. Fatores a serem considerados na utilização de Beauveria bassianavisando o manejo de populações de Alphitobius diaperinus em aviários comerciais. Arquivos do Instituto Biológico 2008;75(3):13-20. 
Alves, LFA, Oliveira DGP, Lambkin T, Bonini AK, Alves VM, Pinto, FGS, Scur MC. Beauveria bassiana applied to broiler chicken houses as biocontrol of Alphitobius diaperinus Panzer (Coleoptera: Tenebrionidae), an avian pathogens vector. Revista Brasileira de Ciência Avícola 2015; 17(4); 459-466.

Alves SB, Ferraz RCCB, Castello-Branco Jr A. Chaves para identificação de patógenos de insetos. In: Alves SB, editor. Controle microbiano de insetos. 2ªed. Piracicaba, FEALQ; 1998a. p. 217-238.

Alves SB, Moino Jr A, Almeida JEM. Produtos fitossanitários e entomopatógenos. In: Alves SB, editor. Controle microbiano de insetos. $2^{a}$ ed. Piracicaba: FEALQ; 1998a. p. 217-238.

Alves SB. Fungos entomopatogênicos. In: Alves SB, editor. Controle microbiano de insetos. $2^{a}$ ed. Piracicaba: FEALQ; 1998. p. 308-310.

Anderson TE, Roberts DW. Compatibility of Beauveria bassianaisolates with insecticide formulations used in colorado potato beetle (Coleoptera: Chrysomelidae) control. Journal Econonomic Entomology 1983;76(6):1437-1441.

Axtell RC. Poultry integrated pest management: status and future. Integrated Pest Management Reviews 1999;(4): 53-73.

Bacon CW. Effects of broiler litter volatiles and ammonia on fungal spore germination. Poultry Science 1985;65(4):710-716.

Barci L, Wenzel IM, Almeida JEM, Nogueira AHC, Prado AP. Compatibilidade de isolados de Beauveria bassiana (Ascomycetes: Clavicipitaceae) com carrapaticidas químicos utilizados no controle do carrapato dos bovinos. Revista Brasileira Parasitologia Veterinária 2009;18(1):63-68.

Bellaver C, Costa CF, Figueiredo EAP, Jaenisch FRF, Favero JA, Palhares $J C P$, et al. Boas práticas de produção de frangos. Concórdia: Embrapa Suínos e Aves; 2003

Boucias DG, Pendlan JC, Latge JP. Nonspecific factors involved in attachment of entomopathogenic deuteromycetes to host insect cuticle. Applied and Environmental Microbiolog 1988;54(7):1795-1805.

Brasil. Ministério da Agricultura e do Abastecimento. Instrução normativa das legislações SDA n78/2003 [cited 2013 Fev 5]. Diário Oficial [da] República Federativa do Brasil, Brasília, DF, 5 nov. 2003. Available from: http://www.agricultura.gov.br/.

Chernaki-Leffer AM, Sosa-Gomez DR, Almeida LM. Selection for entomopathogenic fungi and LD50 of Metarhizium anisopliae (Metsch.) Sorok. for the lesser mealworm Alphitobius diaperinus (Panzer) (Coleoptera: Tenebrionidae).Revista Brasileira Ciência Avícola 2007;9(3):187-191.

Feng MG, Poprawski TJ, Khachatourians GG. Production, formulation and application of the entomopathogenic fungus Beauveria bassiana for insect control: current status. Biocontrol Science and Technology 1994;4(1):3-34.

Ferreira DF. SISVAR: a computer statistical analysis system. Ciência e Agrotecnologia 2011;35(6):1039-1042.

Geden CJ, Arends JJ, Ruttz DA, Steinkraus DC. Laboratory evaluation of Beauveria bassiana (Moniliales: Moniliaceae) against the lesser mealworm, Alphitobius diaperinus (Coleoptera: Tenebrionidae), in poultry litter, soil and a pupal trap. Biological Control 1998;13(2):7177.

Ghini R, Kimati H. Resistência de fungos a fungicidas. Jaguariúna: EMBRAPA Meio Ambiente; 2000.

Haas-Costa J, Alves LFA, Daros AA.Safety of Beauveria bassiana (Bals.) Vuill. to Gallus domesticus L. Brazilian Archives of Biology Technology 2010;53(2):465-471.
Hazeleger WC, Bolder NM, Beumer RR, Jacobs-Reltsma WF. Darking beetles (Alphitobius diaperinus) and their larvae as potential vectors for the transfer of campylobacter jejuni and Salmonella enterica serovar Paratyphi B variant Java between successive broiler flocks. Applied and Enviromental Microbiology 2008;22(4):6887-6891.

Jaenisch FRF, Kuchiishi SS, Coldebella A. atividade antibacteriana de desinfetantes para uso na produção orgânica de aves. Ciência Rural 2010;40(2):384-388.

Khalil SK, Shah MA, Naeem M. Laboratory studies on the compatibility of the entomopathogenic fungus Verticillium lecanii with certain pesticides. Agriculture, Ecosystems \& Environment 1985;13(3-4):329334.

Kimati H. Controle químico. In: Bergami Filho A, Kimati H, Amorin L, editores. Manual de fitopatologia. São Paulo: Agronomica Ceres; 1995.

Lecuona RE, Díaz BM. Susceptibilidad de Spodoptera frugiperda (J. E. Smith) a los hongos entomopatógenos Nomuraea rileyi, Metarhizium anisopliae y Beauveria bassiana. Revista Investigación Agropecuaria $2001 ; 30(1): 25-42$

Lecuona RE, Edelstein JD, Berretta MF, La Rossa FR, Arcas JA. Evaluation of Beauveria bassiana (Hyphomycetes) strains as potential agents for control of Triatoma infestans (Hemiptera: Reduviidae). Journal Medical Entomology 2001;38(2):172-179.

Mcdonnell G, Russel AD. Antiseptics and disinfectants: activity, action, and resistance. Clinical Microbiology Reviews 1999;12(1):147-179.

Moino Junior A, Alves SB. Efeito de imidacloprid e fipronil sobre Beauveria bassiana (Bals.) Vuill., e Metarhizium anisopliae (Metsch.) Sorok., no comportamento de limpeza de Heterotermes tenuis (Hagen). Anais da Sociedade Entomológica do Brasil 1998;30(2):611-619.

Moore-Landecker E. Fundamentals of the fungi. New Jersey: Prentice-Hall; 1982.

Oliveira DGP. Proposta de um protocolo para avaliação da viabilidade de conídios de fungos entomopatogenicos e determinação da proteção ao calor conferida a Beauveria bassiana e Metarhizium anisopliae pela formulação em óleo emocionável [dissertation]. Piracicaba (SP): Escola Superior de Agricultura Luiz de Queiroz; 2009.

Oliveira RC, Neves PMOJ. Compatibility of Beauveria bassiana with acaricides. Neotropical Entomology 2004;33(3):353-358.

Omalu ICJ, Jibrin A, Olayemi IK, Hassan SC, Mgbemena C, Mgbemena A et al. Seroprevalence of malaria and Hepa titiB (HBsAg) with associated risk factors among pregnant women attending antenatal clinic in General Hospital Minna, North-central Nigeria. Annual Review and Research in Biology 2012;2(4): 83-88.

Penha GAS, Ueda EY, Santos F, Peres ERP. Diagnóstico da salmonelose e a sua importância para a avicultura: Revisão de Literatura. Revista Científica Eletrônica de Medicina, Veterinária 2008;6(10).

Ristow, L. E. Desinfetantes e desinfecção em avicultura. Revista Ave world [online], edição 29, 2008. Disponível em: http://www. agrolink.com.br/ saudeanimal/NoticiaDetalhe.aspx?codNoticia=73085

Rohde C, Alves LFA, Neves PMOJ, Alves SB, Da Silva ERL, De Almeida JEM. Seleção de Isolados de Beauveria bassiana (Bals.) Vuill. e Metarhizium anisopliae (Metsch.) Sorok. contra o Cascudinho Alphitobius diaperinus (Panzer) (Coleoptera: Tenebrionidae). Neotropical Entomology 2006;35(2):231-240.

Rossi-Zalaf LS, Alves SB, Lopes RB, Silverira Neto S, Tanzini MR. Interação de microrganismos com outros agentes de controle de pragas e doenças, In: Alves SB, Lopes RB, editores. Controle microbiano de pragas na América Latina: avanços e desafios. Piracicaba: FEALQ; 2008. p.279302. 
Santoro PH, Neves PMOJ, Alexandre TM, Gavaguchi AS, Alves LFA. Carcinops troglodytes (Erichson) (Coleoptera: Histeridae) predando larvas de Alphitobius diaperinus (Panzer) (Coleoptera: Tenebrionidae) em aviários. Neotropical Entomology 2010;39(5):831-832.

Santos JC, Alves LFA, Opazo MAU, Mertz NR, Marcomini AM, Pinto DGO, et al. Eficiência da aplicação de inseticida químico no solo para o Controle de A/phitobius diaperinus Panzer (Coleoptera: Tenebrionidae) em aviário de frango de corte. Arquivos Instituto Biológico 2009;76(3):417-425.

Silva EM, Duarte A. Salmonella Enteritidis em aves: retrospectiva no Brasil. Revista Brasileira de Ciência Avícola 2002;4(2):85-100.

Silva M, Esposito E. O papel dos fungos na recuperação ambiental In: Esposito E, Azevedo JL, coordenadoes. Fungos: uma introdução à biologia, bioquímica e biotecnologia. Caxias do Sul: EDUCS; 2004. p.337-369.

Silva RZ, Neves PMOJ, Santoro PH. Técnicas e parâmetros utilizados nos estudos de compatibilidade entre fungos entomopatogênicos e produtos fitossanitários. Semina: Ciências Agrárias 2005;26(3):305312.
St Leger RJ, Goettel M, Roberts DW, Staples RC. Prepenetration events during infection of hostcuticle by Metarhizium anisopliae. Journal of Invertebrate Pathology 1991;58(2):168-179.

Steinkraus DC, Geden CJ, Rutz DA. Susceptibility of Lesser mealworm (Coleoptera: Tenebrionidae) to Beauveria bassiana: effects of host stage, formulation, substrate and host passage. Journal of Medical Entomology 1991;28(3):314-321.

Todorova SI, Coderre D, Duchesne RM, Côté JC. Compatibility of Beauveria bassianawith selected fungicides and herbicides. Environmental Entomology 1998;27(2):427-433.

Xiao G, Ying SH, Zheng P, Wang ZL, Zhang S, Xie XQ, et al. Genomic perspectives on the evolution of fungal entomopathogenicity in Beauveria bassiana. Scientific Reports 2012;(2):1-10. 